\begin{tabular}{|c|c|}
\hline & Volume \& Issues Obtainable at The Women University Multan \\
Annals of Social Sciences and Perspective \\
ISSN: 2707-7063, Volume 2, No.1 June 2021
\end{tabular}

\title{
Oil Price Hike, Debt Burden and Poverty in Pakistan
}

\section{Muhammad Zahir Faridi ${ }^{1}$, Khawaja Asif Mehmood ${ }^{2}$, Ramsha Anwer}

${ }^{1}$ Professor, School of Economics, Bahauddin Zakariya University Multan, Pakistan.

${ }^{2}$ Assistant Professor, School of Economics, Bahauddin Zakariya University Multan, Pakistan.

${ }^{3}$ M.Phil Scholar, School of Economics, Bahauddin Zakariya University Multan, Pakistan.

\begin{tabular}{lr}
\hline ARTICLE DETAILS & \\
\hline History: & \\
Received: & May 18, 2021 \\
Review: & June 24, 2021 \\
Accepted: & June 28, 2021 \\
Available Online: June 30, 2021 \\
\end{tabular}

\section{Keywords:}

Value of Money, Infant Mortality Rate, External Debt, Literacy Rate, ARDL model.

\begin{abstract}
Hiked oil prices have always heightened the debt burden of an economy and poverty too. Pakistan as a developing country has also been facing this crisis since its inception. Therefore, in this study, the data of the probed variables have been collected from the period ranging from 1972-2019. Auto-regressive Distributive Lag Model has been employed as a methodology, for throwing light on the results of the short run along with the long run. For inspecting the research, the head count ratio is used as the dependent variable. Whereas, factors such as gross domestic product, foreign direct investment, infant mortality rate, literacy rate, unemployment rate, external debt, oil prices, and investment are used as the independent ones. The results of the study disclosed that the coefficient of all independent variables has a positive association with poverty in both the long and short run except GDP and investment. However, the GDP and investment coefficients are found to be significant in the short run and insignificant in the results of the long run. The study depicted several trends with the passing years and suggested some policy measures which, if adopted, might lead to clear the bleak picture of the economy.
\end{abstract}

(C) 2021 The Authors, Published by WUM. This is an Open Access Article under the Creative Common Attribution Non Commercial 4.0

Corresponding author's email address: khawjaasif@bzu.edu.pk

\section{Introduction}

Oil prices have always remained a hot topic in the global market. It serves as a variable that determines the economic activity of any country. Though the geographical location of Pakistan has not shifted yet this factor has made the country face doldrums in various periods among the other countries of Asia. It has marked a shift in terms of its identity and association. Pakistan is ranked fifth among the countries with a population base which is exceeding about 212,742,631 people. Furthermore, it also owns the honor of being the largest 
producer and food supplier and other crops like sugarcane, wheat, cotton and rice. A contribution of about more than 75 percent of the value of total crop output is made by Pakistan. A report by Food and Agriculture Organization (FAO) comes up with the fact that in 2005 the country produced about 21,591,400 metric tons of wheat and in 2012 the output was about 23 million tons. As far as various social, political and economic issues are concerned, a few of these include unbalanced birth and death rates, social safety nets, unemployment and corruption. These crises not only lead to hindrance in the wealth circulation but also magnify the level of inflation. As a result, it escalates the debt burden and leads to currency devaluation. Hence, it also widens the circle of poverty and unemployment in the country. In general, Adam Smith, the father of economics remarks poverty as the incompetence of affording necessities required by the nature. The Department of Health and Human Services (HHS) assigns the status of poor to those who are not able to meet a certain income threshold. In the case of Pakistan, a rise in the level of current account deficit, debt burden and inflation are among the problems that are no less than havoc for the poor. Moreover, the study comprises various objectives. First of which is to validate the rise in oil prices and its domination on the poverty level in Pakistan. Secondly, to certify the aftermath of the debt burden on poverty. Thirdly, assess the causal relationship among the variables.

\section{Relationship among Oil Price Hike, Debt Burden and Poverty}

The rise in debt burden leads to the rise in oil prices which further accredits the price of raw materials to rise. Furthermore, it augments the cost of production as well as the transportation cost. Hitherto, it leads to a fall in the value of the money supply and also a decline in the purchasing power of the consumer. It then lowers consumption and inclines the level of poverty.

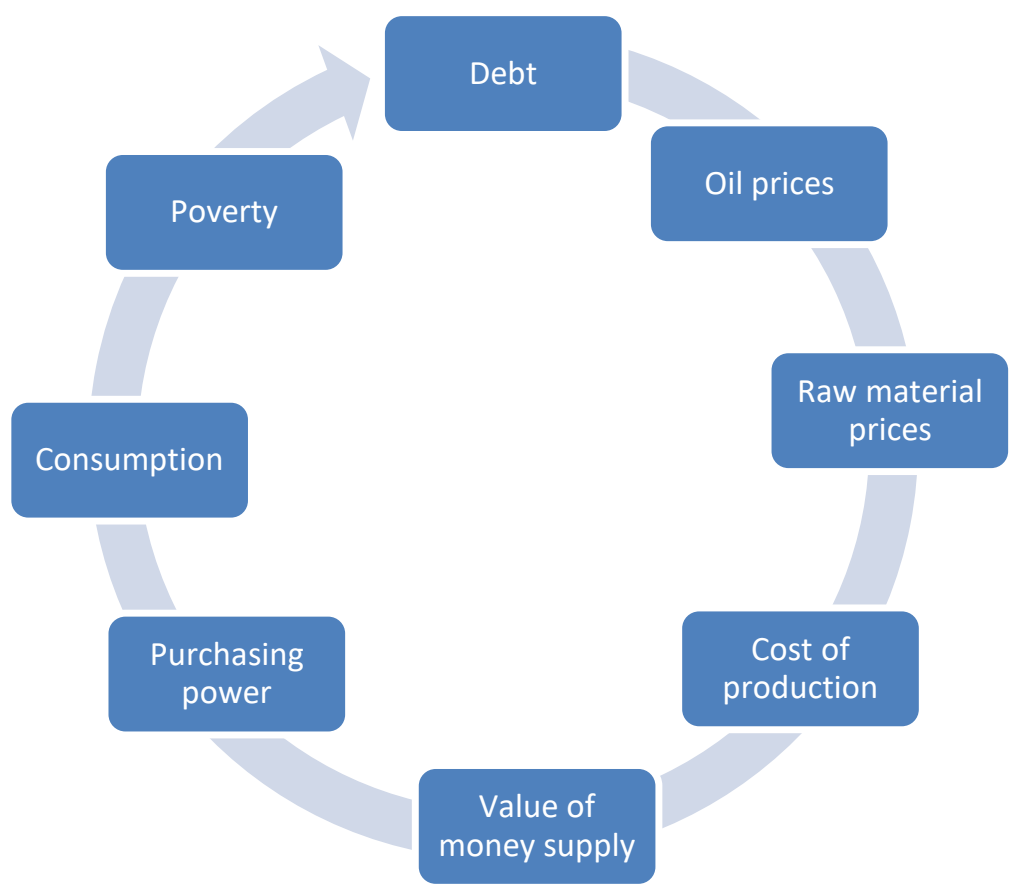

Figure 1: Relationship among Oil Price Hike, Debt Burden and Poverty

Figure 1 illustrates that an escalation in the burden of debt augments the prices of oil which enables a rise in the value of raw material, cost of production and transportation cost. It, 
therefore, results in the fall in the value of money supply, purchasing power of the consumer, level of consumption and ultimately an incline in the level of poverty. An increase in the prices of oil leads to inflation and also lowers the subsidies that are provided by the government. It widens the circle of the unequal distribution of wealth. In a nutshell, it raises the level of debts so that the basic needs may be met and leads to the augmentation in the poverty.

\section{Appraisal of the Literature}

As elaborated by economist Kemal (2001), Pakistan needs such policies which are favorable not only economically but also politically and socially. He highlighted numerous variables that proved infertile and led to the fall in intensity of growth of the economy. One of those variables was a fall in the real wage which made one third of the population to creep below the poverty line. Moreover, the opposite levels of fiscal deficit and balance of payment made the external debt rise evenly. As the debt crisis unbridled, it made the level of poverty rise at an increasing rate. In addition to it, Dijikstra and Niels (2001) shed light on the impact and extent of service debt payments on the economic growth of various highly indebted poor countries. It was concluded from the results of their findings that growth would be re-attained when uncertainty with respect to debt service was declined. It would also result in improved efficiency in government policies. It was demonstrated by Chowdhury (2001) that there existed strong bonding between debt and growth. However, Easterly (2002) remarked external debt is a key factor that leads the rate of discount to exceed. Moreover, when it comes to the debt owned in accordance with the assets among low income families, it was investigated that such families had twice the burden of it. Debt grew much faster than their income and it affected their resource too (Wagmiller, 2003). But the question that arises here is that what makes this deficit level rise? The answer to it is, due to slackness of mobilization of the domestic resources, scrambling expenditures of public, excess borrowings from both domestic and external sources, and reliance on non-inflationary but lavish borrowings by non-banking and the depreciation observed in the exchange rate (Bilquees, 2003). But if we wanted to have an insight upon poverty as well as the development of humans, Armirah (2004) raised a point in her investigation that poverty reduction can be achieved through good governance and by improving the standard of education and health provided. However, when it comes to the determinants of external indebtedness, poverty and various external factors played their havocking role (Tiruneh, 2004). As far as poverty is concerned, the augmented spending of the public related to the reduction in public programs, the funds were used for explicit purposes. It directly reached the poor thus relieving debt (Gupta et al, 2004). The same role was played by rising prices of oil which showed a determined relationship between energy and development. This relationship was determined by several vulnerability components as well as variations in crude oil price. This rise in oil price dropped the national output, changed the spending structure and construction and resulted in a fall in the economic growth of the country. In addition to it, Industrial progress can be checked by the level of energy consumption and the standard of living. As it was felt that consumption of commercial energy was required by economic growth to increase rapidly. It was revealed that the brunt of rising oil prices was faced more by poor households and low income countries (Nkomo, 2006). It was further elaborated that the rise in the prices of oil results in a rise in the prices of necessities, metals and raw materials (Baffes, 2007). It affects not on their debt owned but also indirectly their health. It affects not only psychological health but also physical health. As debt and repayment structure had direct relation health seeking behavior. Indeed, worry affects indirectly the managing capacity of debt (Lenton and Mosley, 2008). What should one do to eradicate poverty while achieving sustainable growth of the country? 
Zafar and Sabihuddin (2008) answered it through their investigation of it in the case of Pakistan. They researched that external debt burden was influenced by the exchange rate and they had a negative but significant relationship between them. It showed that improving revenues earned through exports would result in reducing exports, in the case when a high exchange rate was provided. Hitherto, this issue might be resolved by developing new industries. As we have discussed poverty and debt up till now. One might think that who is the debt poor? Pressman and Scott (2009) sighted and declared the debt poor as those that belong to the middle class due to their access to consumer credit and have large debt burden due to income loss, placing them below the poverty criteria. Additionally, a channel that affects each other includes various variables like, economic growth influenced the government debt included private saving, and public investment and total factor productivity, sovereign long term nominal and real interest rate (Checherita and Rother, 2010). Furthermore, the rise in oil prices influences the consumption pattern of households on daily basis and also the real GDP growth (Kiani, 2011). GDP per capita is negatively influenced by the impact of domestic debt and the association is significant (Akram, 2011). However, national per capita income and per capita income affect the external debt burden unfavorably (Boboye and Michael, 2012).

\section{Data Source and Methodological Issues}

The secondary mode of data is probed in this study. Data ranging from 1972-2019 and is time series in nature has been collected of various variables for scrutinizing their relationship with hiked oil prices in Pakistan. The statistics have been collected from various sources including the World Bank organization, the State Bank of Government, International Monetary Fund, Handbook of Statistics and the Government of Pakistan Economic Survey (2018-19). The model has been specified in the Autoregressive Distributive Lag as the variables available are a mix. Moreover, the Pair-Wise correlation of the variables is initiated to explore the nature and level of association among them. Various steps are involved in the analysis. The stationarity of the variables is checked by using the unit root test, co-integration and lag selection criterion. For determining the long run relationship between the dependent and the independent variables co-integration is carried. Therefore, the Autoregressive Distributive Lag Model is applied to it. The model specified is started as below:

$\mathrm{HCR}=\mathrm{f}(\mathrm{GDP}, \mathrm{LTR}, \mathrm{IMR}, \mathrm{OPR}, \mathrm{INV}, \mathrm{FDI}, \mathrm{EDT}, \mathrm{UNR})$

$\mathrm{HCR}=\alpha-\mathrm{B} 1 \mathrm{GDP}+\mathrm{B} 2 \mathrm{LTR}+\mathrm{B} 3 \mathrm{IMR}+\mathrm{B} 4 \mathrm{OPR}-\mathrm{B} 5 \mathrm{INV}+\mathrm{B} 6 \mathrm{FDI}+\mathrm{B} 7 \mathrm{EDT}+\mathrm{B} 8 \mathrm{UNR}+\varepsilon$

Here, HCR denotes poverty which is a dependent variable. However, the others variables included in the model are independent. It is also explored as the mixed order of integration.

Table 1: Description of the Variables

\begin{tabular}{llll}
\hline \multicolumn{1}{c}{ Variable } & \multicolumn{1}{c}{ Definition } & \multicolumn{1}{c}{ Expected relation } & \multicolumn{1}{c}{ Measurement unit } \\
\hline HCR & Headcount ratio & Dependent variable & Percentage \\
\hline GDP & Gross domestic debt & Negative & Million rupees \\
\hline LTR & Literacy rate & Positive & Percent \\
\hline IMR & Infant mortality rate & Positive & Per 1000 children \\
\hline OPR & Oil prices & Positive & Rupees \\
\hline INV & Investment & Negative & Million rupees \\
\hline FDI & Foreign direct investment & Positive & Million rupees \\
\hline EDT & External debt & Positive & Million rupees \\
\hline
\end{tabular}




\begin{tabular}{lll}
\hline UNR & Unemployment rate & Positive \\
\hline
\end{tabular}

\section{Description of the Variables}

The various variables are described as follows:

\section{Poverty (HCR)}

It is the criterion assigned globally to the population by the World Bank. It states that those who fall under $\$ 1.90$ per day are among the poor. It is accounted for by dividing the total number of people falling under the mentioned criterion by the total population. Previously the criterion to measure poverty was set up as $\$ 1.25$.

\section{Gross Domestic Product}

The International Monetary Fund defines the Gross Domestic Product as the measure that is purchased by the final user in the form of the goods and services that are produced in a country within a given period.

\section{Infant Mortality Rate}

The number of infants who died before reaching their first birthday are represented and counted in the infant mortality rate. It is measured by dividing the number of deaths of children less than one year by 1000 live births, infant mortality rate generally rises due to the poverty associated conditions and low living standards of the people. Not only does it affect the physical condition of the human but also leaves them prone to several other diseases and raises the level of poverty thus affecting the health of the mother as well as the child.

\section{Oil Prices}

Th e spot price of one barrel of the benchmark crude oil determines the oil price. It depends upon grade, location and sulfur presence. Oil prices are determined by maintaining the balance between demand and supply it.

\section{Investment}

Spending on goods that further create wealth is known as investment. It can be acquired in the form of an asset to generate income from it. It has a negative association with poverty. The rise in investment in ventures leads to an increase in savings and a fall in the level of unemployment. The more the individuals are employed, the more they would improve standards of living and would also enhance the gross domestic product of the country. Hitherto, an incline in investment leads to a decline in poverty.

\section{Foreign Direct Investment}

It is the investment made by any foreign firm or any individual of any country in ventures situated in the other country. An augment in FDI leads to a decline in the poverty faced in the country. As it unlocks the door to several opportunities and boosts the growth of the economy.

\section{External Debt}


The debt which a government borrows from various sources including commercial banks, governments, or any international financial institutions is known as the external debt.

Unemployment Rate: Unemployment represents those workers that are willing to work as well as being able to work but are unable to find any job. The unemployment rate determines the unemployed workers in the total labor force.

\section{Results and Discussion}

Table 2: Descriptive Statistics of the Selected Variables:

\begin{tabular}{llllllllll}
\hline & GDP & LTR & IMR & OPR & INV & FDI & EDT & UNR & HCR \\
\hline Mean & 14.36 & 3.67 & 4.44 & 3.29 & 12.7 & 9.22 & 10.03 & 0.44 & 50.46 \\
\hline Median & 14.50 & 3.69 & 4.44 & 3.30 & 12.8 & 9.68 & 10.17 & 0.55 & 53.60 \\
\hline Maximum & 17.12 & 4.15 & 4.84 & 4.69 & 15.6 & 12.9 & 11.00 & 1.45 & 64.30 \\
\hline Minimum & 10.90 & 3.07 & 4.11 & 0.59 & 9.06 & 4.66 & 8.15 & -0.69 & 27.30 \\
\hline Std.Dev & 1.82 & 0.34 & 0.81 & 0.87 & 1.90 & 2.69 & 0.73 & 0.47 & 8.60 \\
\hline Skewness & -0.18 & -0.20 & -0.13 & -0.59 & -0.15 & -0.21 & -0.66 & -0.28 & -1.31 \\
\hline Kurtosis & 1.82 & 1.59 & 2.22 & 4.03 & 1.88 & 1.69 & 2.83 & 2.44 & 3.63 \\
\hline Jarque-Bera & 3.06 & 4.27 & 1.33 & 5.01 & 2.68 & 3.80 & 3.54 & 1.27 & 14.60 \\
\hline Probability & 0.21 & 0.11 & 0.51 & 0.08 & 0.26 & 0.14 & 0.16 & 0.52 & 0.0006 \\
\hline Sum & 689.5 & 176.2 & 231.4 & 158.1 & 609.8 & 442.6 & 481.8 & 21.3 & 2422.4 \\
\hline Sum Sq. & 156.2 & 5.67 & 1.55 & 35.6 & 171.05 & 341.4 & 25.23 & 10.4 & 3479.1 \\
Dev & & & & & & & & & \\
\hline Observations & 48 & 48 & 48 & 48 & 48 & 48 & 48 & 48 & 48 \\
\hline
\end{tabular}

Table 2 discusses the descriptive statistics of some selected variables. The mean value accounted for head count ratio is 50.46 and that of median, maximum and minimum are $53.60,64.30$ and 27.30 respectively. The skewness sign reflects the fact that it is negatively skewed with a value of about 1.31. The nature of being leptokurtic is being reflected through the value of kurtosis. The value of probability shows that the null would be rejected which means the null hypothesis would be rejected and the alternative would be accepted that residuals of data are normally distributed. Furthermore, the descriptive statistics of the gross domestic product show that $14.36,14.5$ and 10.90 are the values of mean, median, maximum and minimum. It is negatively skewed and is platy kurtic. The null hypothesis of jarque-bera will be accepted which means residual of data is not normally distributed. The literacy rate comes up with a trend where 3.67, 3.69 4.15 and 3.07 are the respective values of formerly told variables of descriptive statistics. The pattern of skewness shows the negative nature whereas the value of kurtosis shows that it is platy. The probability value highlighted the abnormal distribution of the residual data. Infant mortality rates have values of descriptive statistics as $4.49,4.84,4.11$ and 0.81 respectively. The variable is skewed negatively with a platy kurtic shaped. Abnormal data distribution is highlighted through probability value. In addition to these, oil prices though are leptokurtic in nature yet reject the null hypothesis at 10 percent level of significance. Investment is skewed negatively with the values of about $0.15,12.7,12.8$ and 15.6 of mean, median, maximum and minimum. It is represented by the value of probability that residuals of data are distributed normally. The foreign direct investment reflects the trend of being negatively skewed but platy kurtic in nature. The probability value of the variables reflects the normal distribution of the residuals of data. Similarly, the external debt follows the pattern of being skewed negatively and nature of being platy kurtic in nature but denies the pattern of being normally distributed. Lastly, the 
unemployment rate emerges with the trend of being skewed negatively, platy kurtic, abnormal distribution of residuals of data along with having 0.44 as the mean, 0.55 as median, and 1.45 as maximum and -0.69 as the minimum.

Table 3: Pair-wise Correlation Coefficient

\begin{tabular}{lllllllll}
\hline & HCR & GDP & LTR & IMR & OPR & INV & FDI & EDT \\
\hline GDP & -0.59 & & & & & & & \\
\hline LTR & -0.56 & 0.99 & & & & & & \\
\hline IMR & 0.74 & -0.78 & -0.78 & & & & & \\
\hline OPR & -0.60 & 0.80 & 0.76 & -0.67 & & & & \\
\hline INV & -0.62 & 0.99 & 0.98 & -0.79 & -0.79 & & & \\
\hline FDI & -0.56 & 0.97 & 0.98 & -0.76 & 0.73 & 0.98 & & \\
\hline EDT & -0.55 & 0.97 & 0.95 & -0.70 & 0.82 & 0.97 & 0.94 & \\
\hline UNR & -0.39 & 0.63 & 0.67 & -0.64 & 0.39 & 0.62 & 0.65 & 0.54 \\
\hline
\end{tabular}

Table 3 provides the pair-wise degree of the inter correlation among the variables where 59 percent association exists between GDP and poverty. However, it is negative and a moderate one. A negative interdependence emerges between poverty and literacy rate with a rate of about 56 percent. Additionally, a 74 percent strong association exists between infant mortality rate and poverty which is positive in nature. About 60 percent, 62 percent, 56 percent and 39 percent moderate interdependence persists with poverty between investment, foreign direct investment, external debt and unemployment rate respectively. There is 99 percent association with positive nature existing between literacy rate and GDP, whereas, 77 percent strong but negative association prevails between infant mortality rate and GDP. Similarly, a positive relationship exists with oil prices, investment, foreign direct investment and external debt having values of 80 percent, 99 percent, 97 percent and 97 percent respectively. 63 percent positive and moderate association endures between the unemployment rate and GDP and about 67 percent between the unemployment rate and literacy rate. In contrary to these, a negative but moderate interdependence is preserved between the unemployment rate and infant mortality rate. 67 percent moderate but negative relation exists between oil price and infant mortality rate. Moreover, there exists 79 percent with investment, 76 percent with foreign direct investment and 70 percent with external debt. The nature of association among them is positive and strongly interdependent. A positive and strong association exists between oil prices and investment, foreign direct investment and external debt of 79 percent, 73 percent and 82 percent respectively. However, there exists a positive and moderate correlation of 39 percent between unemployment rate and poverty. Furthermore, a positive and strong association persists between foreign direct investment and external debt with investments with values of about 98 percent and 97 percent respectively. A moderate and positive association of 62 percent exists between investment and the unemployment rate. As far as the case of foreign direct investment is concerned, a strong and positive association of 94 percent is present between foreign direct investment and external debt whereas a moderate but positive relation of about 65 percent between foreign direct investment and unemployment rate. Lastly, a moderate interdependence of about 54 percent is seen between external debt and the unemployment rate.

Table 4: Long-Run ARDL Estimates

Dependent variable: HCR 


\begin{tabular}{|c|c|c|c|c|}
\hline Variable & Coefficient & Std. Error & t-Statistic & Prob. \\
\hline GDP & -10.42 & 10.33 & -1.00 & 0.32 \\
\hline LTR & 57.69 & 46.15 & 1.24 & 0.22 \\
\hline IMR & 4.39 & 16.68 & 0.26 & 0.79 \\
\hline OPR & 0.26 & 3.66 & 0.07 & 0.94 \\
\hline INV & -42.66 & 14.9 & -2.86 & 0.008 \\
\hline FDI & 10.19 & 5.11 & 1.99 & 0.05 \\
\hline EDT & 53.79 & 29.09 & 1.84 & 0.07 \\
\hline UNR & 17.05 & 8.73 & 1.95 & 0.06 \\
\hline $\mathrm{C}$ & -137.3 & 161.8 & -0.84 & 0.40 \\
\hline
\end{tabular}

Table 4 describes the long run ARDL estimates of the poverty model. First, we have found that the coefficient of Gross Domestic Product influences poverty negatively but it is insignificant statistically. Poverty is reduced by about 10.42 units due to a one unit increase in Gross Domestic Product. The reason may be that the GDP is a good indicator of economic performance. Secondly, the coefficient of literacy rate demonstrates that though it has a positive influence on poverty yet it is insignificant statistically. Poverty is increased to about 57.69 units with an increase of about one unit in literacy rate. The reason for it might be that an increase in the literacy rate when the individual is still faced with the menace of unemployment, will lead to an upward tilt in the poverty. Thirdly, the coefficient of infant mortality rate depicts that it influences poverty positively. Poverty is raised about 4.39 units with a rise of one unit in infant mortality rate. The possibility is that the infant mortality rate is a clear depiction of the bleak scenario that how the population of the poor countries is living in poverty associated conditions which not only affect their mental but also physical health. Moreover, the coefficient of oil price highlights that it influences poverty positively though it is insignificant statistically. Poverty is raised to 0.26 units with an increase of one unit in oil price. It is because the oil price is the criterion set globally that decides whether the economy would observe an upward trend or a downwards one. Hitherto, the rise in oil prices leads the economies to face the havocs of poverty. The coefficient of investment, when viewed, portrays that it affects poverty negatively but is significant statistically. Poverty will augment up to 42.66 units with a fall of one unit in investment. It is because with the rise in investment there would be more ventures to invest in thus indirectly raising the sources of employment for those who are seeking it. Therefore, it results in a decline in the level of poverty. Then, the coefficient of foreign direct investment illustrates that it has a positive association with poverty and is also significant statistically. Poverty will escalate about 10.19 units with an augment of one unit in the foreign direct investment. It means foreign direct investment when provided to any country in the form of any technology or capital it would lead to the generation of an opportunity to be provided to the skilled labor that is owned by the country providing FDI. Thus, it degrades and drops the employment source of domestic labor and replaces their right to employment. Furthermore, the results reveal that external debt has a positive relationship with poverty and is statistically significant. Poverty will heighten about 53.79 units with an increase of one unit in external debt. The reason is, the more the external debt the more a country would be facing poverty and its impacts. When it comes to the unemployment rate, it has a positive association with GDP and is also statistically significant. One unit rise in the unemployment rate would lead to an escalation of about 17.05 units in poverty. The greater the level of unemployment faced the greater there would be chances of poverty to heighten up.

\section{Table 5: Short-Run Results of the Poverty Model}




\begin{tabular}{|c|c|c|c|c|}
\hline Variable & Coefficient & Std. Error & t-Statistic & Prob. \\
\hline $\mathrm{D}(\mathrm{HCR}(-1))$ & -0.78 & 0.16 & -4.77 & 0.0001 \\
\hline $\mathrm{D}(\mathrm{GDP})$ & -11.4 & 5.01 & -2.27 & 0.03 \\
\hline $\mathrm{D}(\mathrm{GDP}(-1))$ & 4.21 & 3.81 & 1.10 & 0.27 \\
\hline D(LTR) & 19.4 & 19.04 & 1.02 & 0.31 \\
\hline D(IMR) & 1.48 & 5.91 & 0.25 & 0.80 \\
\hline $\mathrm{D}(\mathrm{OPR})$ & 0.08 & 1.24 & 0.07 & 0.94 \\
\hline D(INV) & 5.41 & 6.83 & 0.79 & 0.43 \\
\hline $\mathrm{D}(\mathrm{INV}(-1))$ & 13.8 & 5.67 & 2.44 & 0.02 \\
\hline D(FDI) & 0.06 & 1.24 & 0.05 & 0.95 \\
\hline D(FDI(-1)) & -2.56 & 1.19 & -2.14 & 0.04 \\
\hline $\mathrm{D}(\mathrm{EDT})$ & 9.76 & 16.9 & 0.57 & 0.56 \\
\hline $\mathrm{D}(\mathrm{EDT}(-1))$ & -22.1 & 13.2 & -1.66 & 0.10 \\
\hline D(UNR) & 5.75 & 2.28 & 2.51 & 0.01 \\
\hline CointEq(-1) & -0.33 & 0.17 & -1.89 & 0.06 \\
\hline \multicolumn{5}{|c|}{ Cointeq $=$ HCR $-(-10.4241 *$ GDP $+57.6964 *$ LTR +4.3914} \\
\hline \multicolumn{5}{|c|}{$* \mathrm{IMR}+0.2620 * \mathrm{OPR}-42.6694 * \mathrm{INV}+$} \\
\hline \multicolumn{5}{|c|}{$10.1980 * \mathrm{FDI}+53.7951 * \mathrm{EDT}+17.0535 * \mathrm{UNR}$} \\
\hline \multicolumn{5}{|c|}{$-137.3003)$} \\
\hline
\end{tabular}

In short run results of the poverty model, an indirect relationship persists between gross domestic product and poverty. It reflects that an augment in GDP would ultimately lead to a fall in the level of poverty and vice versa. A relation of the same nature persists between poverty and other selected variables. Poverty is directly affected by various variables including unemployment rate, literacy rate, infant mortality rate, oil prices, external debt, investment, foreign direct investment and unemployment. The probability value of GDP depicts that the rejecting of the null hypothesis at a 5 percent level of significance and acceptance of the alternative hypothesis which means a statistically significant relationship exists between GDP and poverty. It is implied through the probability value of literacy rate that at a 10 percent level of significance the null hypothesis will be accepted leading to the reluctance of alternative and shedding light on the fact that there exists an insignificant association between literacy rate and poverty. An association of the same nature exists between poverty and infant mortality rate, poverty and oil prices. The probability value further highlights that investment is insignificantly linked with poverty but a statistically significant association prevails between external debt and foreign direct investment with poverty. The reluctance of the null hypothesis at a 5 percent level of significance comes up with a result that the unemployment rate and poverty are significantly linked with each other.

In other words, the outcomes of short run disclose that a rise of one percent in GDP will result in a decline in poverty of 11.4 million rupees. Similarly, an increase of one percent in the infant mortality rate would incur a rise of 19.9 percent in poverty. An escalation of one percent in oil price would result in an increase of 0.08 rupees in poverty. An augment of one million rupees in investment will lead to a rise of 5.41 percent in poverty. A rise of about one million rupees in external debt would shift poverty upward to about 0.06 percent. The significant error correction term is used to highlight the long long run relationship (Bannerjee and Mestre, 1998). The speed with which the short run converges or diverges towards the long run is known as the speed of adjustment and it is represented through the error correction term. The coefficient of error correction in the short run reveals that it will converge towards the long run in one year with a speed of 33 percent. 
A study carried by Immimole et al. (2011) reveal that the coefficient of GDP had though negative sign but showed significant outcomes and it was a determinant of external debt that was significant. The results also revealed that they were reliable theoretically which means an escalation in the production of domestic goods and services will reduce the demand for external debt. The failure to cope up with external debt in the short run leads the economies to face several economic problems like depreciation in the exchange rate, the decline in economic growth, hiking fiscal deficit, augmenting external debt servicing and widening roots of corruption (Awan, 2011). Moreover, the rise in petroleum prices resulted in a decline in the level of the unemployment rate, poverty and GDP. It obstructed not only growth but also development of the economy (Sanni, 2014). The rise in the level of unemployment and population growth heightens up the level of poverty (Aiyedogbon and Ohwofasa, 2012). Poverty further constraints the path to achieving the scope of development (Nkomo J.C, 2006). Furthermore, inflation is exaggerated by a rise in crude oil prices and both showed statistically significant associations (Shaari, 2012). Economic growth is also affected by hiking oil prices (Ibrahim A. et al. 2014). It leads the economic growth to decline at a pace (Nkomo, 2006). It affected the consumption pattern of consumers on daily basis (Kiani, 2011). In the case of a decline in investment, an ascending pattern is observed in debt-income ratio and a descending pattern is seen in the economic growth (Ibrahim, 2015). It was proposed that economic growth and per capita GDP are enhanced by an increase in investment (Akram, 2011).

\section{Conclusion}

The study has discussed the pattern of hiking oil prices and its impacts on poverty in Pakistan that proved as a burden on the economy as it augmented the debt burden. The analysis is based on secondary data. For methodology, the Autoregressive Distributive Lag Model has been employed. The results of the study reveal that except gross domestic product and investment all other independent variables including literacy rate, infant mortality rate, unemployment rate, oil prices, foreign direct investment and external debt have a positive relationship with poverty in both the long and the short run. In contrast to it, the coefficients of GDP and investment are significant in the results of long run. The study further needs to find out the association of selected variables in accordance with the menace of corruption and political instability in the country. Based on the outcomes of the probing following measures should be adopted by the state to tackle with the rising level of poverty:

Maintenance of oil prices to the level that should be a little less than that of global as it is the leading source of promoting poverty. The lower the oil prices the lower would be poverty.

A preference should be made towards renewable energy resources so that reliance on oil should be minimized. It will also reduce the debt burden on the economy.

Subsidized health care opportunities, housing and free education should be provided by the state to cope up with the menace of poverty and improve the standards of development in the country.

For coping up with unemployment, such projects should be employed that are productive so that the investment might be used to initiate other projects of such nature.

The state should focus on improving the security conditions as it will assist them to invite more foreign direct investment in the country rather than aid. 


\section{References}

Aiyedogbon, J. O., \& Ohwofasa, B. O. (2012). Poverty and youth unemployment in Nigeria, 1987-2011. International Journal of Business and Social Science, 3(20).

Ajayi, L. B., \& Oke, M. O. (2012). Effect of external debt on economic growth and development of Nigeria. International journal of business and social science, 3(12), 297-304.

Akram, N. (2011). Impact of Public Debt on the economic growth of Pakistan. The Pakistan Development Review, 50(4) 599-615.

Arimah, B. (2004). Poverty reduction and human development in Africa. Journal of Human Development, 5(3), 399-415.

Awan, A., Asghar, N., \&Rehman, H. U. (2011).The impact of the exchange rate, fiscal deficit and terms of trade on the external debt of Pakistan. Australian Journal of Business and Management Research, 1(3), 10.

Baffes, J. (2007). Oil spills on other commodities. The World Bank.

Banerjee, A., Dolado, J., \& Mestre, R. (1998). Error-correction mechanism tests for cointegration in a single-equation framework. Journal of time series analysis, 19(3), 267-283.

Bilquees, F. (2003), An Analysis of Budget Deficits, Debt Accumulation, and Debt Instability. The Pakistan Development Review, 42(3) 177-195.

Checherita-Westphal, C. D., \&Rother, P. (2010). The impact of high and growing government debt on economic growth: an empirical investigation for the euro area. Working Paper no. 1237.

Chowdhury, A. R. (2001) External Debt and Growth in Developing Countries; A Sensitivity and Causal Analysis. (WIDER Discussion Paper No. 2001/95).

Dijkstra, G., Niels, H. (2001), "The Uncertainty of Debt Service Payments and Economic Growth of Highly Indebted Poor Countries: Is There a Case for Debt Relief?" Helsinki, WIDER Discussion Paper No. 122

Easterly, W. (2002), "How Did Heavily Indebted Poor Countries Become Heavily Indebted? Reviewing Two Decades of Debt Relief". World Development, 30(10),1677-1696.

Gupta, S., Clements, B., Guin-Siu, M. T., \& Leruth, L. (2002). Debt relief and public health spending in heavily indebted poor countries. Bulletin of the World Health Organization, 80(2), 151-157.

Gupta, S., Clements, B., Guin-Siu, M. T., \&Leruth, L. (2004).Debt relief and public health spending in heavily indebted poor countries. Health and, 26.

Ibrahim, M. H. (2015). Oil and food prices in Malaysia: a nonlinear ARDL analysis. Agricultural and Food Economics, 3(1), 1-14.

Imimole, B., Imoughele, L. E., \& Okhuese, M. A. (2014). Determinants and sustainability of external debt in a deregulated economy: A cointegration analysis from Nigeria (19862010). American International Journal of Contemporary Research, 4(6), 201-214.

Kemal, A. R. (2001). Debt accumulation and its implications for growth and poverty. The Pakistan Development Review, 40(4), 263-281.

Kiani, A. (2011). Impact of high oil prices on Pakistan's economic growth. International Journal of Business and Social Science, 2(17), 209-216.

Lenton, P., \& Mosley, P. (2008).Debt and health.

Nkomo, J. C. (2006). The impact of higher oil prices on Southern African countries. Journal of Energy in Southern Africa, 17(1), 10-17.

Pressman, S., \& Scott, R. H. (2009). Who is the debt poor?. Journal of Economic Issues, 43(2), 423-432. 
Sanni, I. M. (2014). The implications of price changes on petroleum products distribution in Gwagwalada Abuja, Nigeria. J. Energy Technol. Policy, 4(7), 1-7.

Shaari, M. S., Hussain, N. E., \& Abdullah, H. (2012). The effects of oil price shocks and exchange rate volatility on inflation: Evidence from Malaysia. International Business Research, 5(9), 106-112.

Tiruneh, M. W. (2004). An empirical investigation into the determinants of external indebtedness. Prague economic papers, 13(3), 261-277.

Wagmiller, R. L. (2003). Debt and assets among low-income families.

Zafar, S. \& Butt, M. S. (2008), Impact of Trade Liberalization on External Debt Burden: Econometric Evidence from Pakistan. MPRA Paper No. 9548. 